\title{
National interest to global reform: patterns of reasoning in British foreign policy discourse
}

Article

Accepted Version

Humphreys, A. R. C. (2015) National interest to global reform: patterns of reasoning in British foreign policy discourse. The British Journal of Politics and International Relations, 17 (4). pp. 568-584. ISSN 1369-1481 doi:

https://doi.org/10.1111/1467-856X.12053 Available at https://centaur.reading.ac.uk/38528/

It is advisable to refer to the publisher's version if you intend to cite from the work. See Guidance on citing.

To link to this article DOI: http://dx.doi.org/10.1111/1467-856X.12053

Publisher: Wiley

Publisher statement: 'The definitive version is available at wileyonlinelibrary.com'.

All outputs in CentAUR are protected by Intellectual Property Rights law, including copyright law. Copyright and IPR is retained by the creators or other copyright holders. Terms and conditions for use of this material are defined in the End User Agreement.

www.reading.ac.uk/centaur

\section{CentAUR}


Central Archive at the University of Reading

Reading's research outputs online 


\section{From National Interest to Global Reform: Patterns of Reasoning in British Foreign Policy Discourse}

On 18 April 2008, Prime Minister Gordon Brown (2008a, 27) laid out a reformist vision of a 'new global society founded on revitalised international rules and institutions, and grounded in the great values we share in common'. He argued that the emergence of new, global challenges such as climate change, terrorism, nuclear proliferation, poverty, and the recent financial crisis required genuinely global solutions, and that those solutions required sweeping reforms to the existing global order. He also claimed that the basic goals of British foreign policy could only be fulfilled if such challenges were met. This implied a striking extension of the content of the national interest beyond its conventional association with national security (itself often quite narrowly construed): Brown not only advocated global reform, but also identified it as a British national interest, that is, as a means of achieving underlying national goals.

Although Brown's call for the development of a 'truly global society' became a touchstone of his foreign policy discourse as PM (see Brown 2008b; 2009a; 2010a), it has received little academic attention. This is surprising, not least because in articulating his vision of a reformed global order Brown explicitly sought to move beyond Tony Blair's (1999) doctrine of international community. ${ }^{1}$ My interest, however, is less in Brown's attempt to carve out a distinctive foreign policy position (see Seldon and Lodge 2010) than in the pattern of reasoning he employs in articulating the British national interest. For whereas national interests are often inferred from existing policies and commitments, Brown links them to the fulfilment of deeper national goals. Indeed, his defence of global reform as a British national interest represents the apogee of a two-pronged trend in New Labour's foreign policy discourse. That trend encompassed, first, an increasingly explicit reformist approach to the national interest, the starting point for which was articulation of the fundamental goals foreign policy was intended to serve, and second, an increasing tendency to identify global order as an object of foreign policy, and hence as subject to reform, rather than conceiving of it merely as the context in which interests are pursued and to which foreign policy must react.

In what follows I aim to show that claims about national interests are most helpfully understood as claims about how putative national goals are best pursued under certain conditions. Although this kind of means-ends reasoning is rarely spelled out, it is what distinguishes claims about interests from claims about preferences (Kratochwil 1982): a meaningful claim about the national interest is distinguished from a mere preference about policy (in relation to which 'the national interest' may be invoked rhetorically, as a means of garnering support) by its reasoning 
about how postulated interests advance more fundamental goals. Sometimes such reasoning will be explicit, but often it will need to be brought out into the open through critical analysis. Meaningful evaluation of claims about the national interest will then depend on our ability to reconstruct the pattern of reasoning which links policies claimed to be in the national interest to underlying national goals.

I contend that this link between goals and interests can typically be reconstructed by reference to one of two ideal-typical patterns: reformist and conservative. In brief, reformist approaches start by specifying what the national goals are or should be, and then infer interests from those goals, given a certain understanding of present and likely future conditions, while conservative approaches start by identifying existing commitments, associate them with current enjoyment of certain national goods, and infer that those commitments should, in the national interest, be maintained. As ideal-types, these patterns offer two distinct but related benefits. First, they can help illuminate the content of foreign policy discourses. For example, the 2006 Foreign and Commonwealth Office [FCO] White Paper (FCO 2006: 28) identifies '[p]romoting sustainable development and poverty reduction underpinned by human rights, democracy, good governance and protection of the environment' as a strategic international priority. This may be reconstructed as a reformist claim about the importance of such policies, given current conditions, for achieving core national goals such as security and prosperity. Second, these patterns can help to hold to account those who would appeal to 'the national interest' to defend or justify a particular policy. Being able to expose when such claims are empty (because they lack relevant means-ends reasoning) or to reveal their conditions of acceptability (the putative national goals are desirable and the proposed policies are plausibly the best means of pursuing those goals) is a potentially powerful political tool.

My argument proceeds as follows. In the next section I examine the concept of the national interest, arguing that appeals to it are meaningful, but inherently contestable. In the following section I lay out the ideal-typical distinction between reformist and conservative approaches and consider to what extent it maps onto party-political divisions over foreign policy. The third section illustrates the utility of this distinction by showing how New Labour's foreign policy discourse was frequently shaped by (often quite explicit) reformist reasoning about the national interest. The fourth section explores how this reformist reasoning justified a commitment to global institutional reform which culminated in Brown's vision of a new global society, a vision which reveals how far the content of the national interest can extend beyond narrow national security concerns when a reformist approach is employed. The conclusion returns to the utility of this approach for holding policymakers to account when they invoke the national interest. 


\section{The Concept of the National Interest}

According to Burchill $(2005,8)$ the national interest is 'a term largely devoid of substantive meaning and content'. It 'may retain rhetorical and lexical functions in the modern age' (2005, $211)$, but if so it should be analysed as a rhetorical device. McCormack $(2011,107)$ concurs: the concept 'has historically been linked with protecting and/or advancing a specific political and economic programme' and hence has 'had a specifically ideological role related to the protection and legitimation of a certain political and social order'. These are important points, but should not be overstated. The national interest cannot be objectively determined, that is, it cannot be identified independently of an intrinsically contestable claim about appropriate national goals. Yet this does not entail that its use is purely rhetorical. If members of a national community differ over what goals are appropriate for that community or over how they are best advanced, then policy-makers may reasonably attempt to mediate these differences (Kratochwil 1982, 9). Moreover, if those who make authoritative decisions defend them by reference to the national interest, then the concept is empirically valuable. Indeed, it is empty rhetoric only when meansends reasoning linking interests to goals is absent (Bull 2002,63). When means-ends reasoning is present, or can be reconstructed, claims about the national interest are meaningful, though inherently contestable. Discursive analysis can therefore illuminate what is at stake in debates about the national interest, even if it cannot resolve them (Nye 1999, 23).

The idea that foreign policies should be oriented towards the fulfilment of national goals begins to look problematic only when putative national goals are shielded from scrutiny and criticism, or when the reasoning that links putative national interests to such goals is inadequate. Both these faults are often attributed to realist claims about national security interests, inviting suspicion that external necessity provides ideological cover for the pursuit of sectional interests. However, realists typically acknowledge that, far from being fixed, interests reflect underlying goals. What distinguishes realists is their prioritization of security as a goal. This prioritization is contestable, but it is wholly consistent with the idea that national interests are means to the fulfilment of underlying national goals.

Burchill $(2005,33)$ represents Morgenthau as believing that national interests are 'a matter of objective reality'. This is misleading. Morgenthau $(1973,5)$ describes the concept of 'interest defined in terms of power' as the 'main signpost that helps political realism to find its way through the landscape of international politics': it provides a 'rational outline, a map that suggests to us the possible meanings of foreign policy'. It does not imply that interests can be 
objectively determined (in the sense given above), but rather functions as an ideal-typical point of departure for analysing foreign policy. Morgenthau $(1973,8-9)$ does describe the 'concept of interest defined in terms of power' as 'an objective category which is universally valid', but he insists that this does not give it 'a meaning that is fixed once and for all'. His point is that the 'idea of interest is ... of the essence of politics'. While we cannot understand politics without the concept of interests (without the idea that policies advance underlying goals), 'the kind of interest determining political action in a particular period of history depends upon the political and cultural context within which foreign policy is formulated'.

None of this implies that interests themselves can be objectively identified, though once certain national goals are agreed, external conditions may effectively determine the content of national interests. Although realists tend to prioritize security as a goal, and hence identify policies that promote national security as being in the national interest, this is consistent with the idea that interests flow from culturally specific understandings both of a nation's ultimate goals and of the conditions under which they are to be pursued (see Williams 2004,638). Thus even for realists national interests advance domestic goals: claims about interests are contestable claims about which goals should be prioritized and about how those goals are best pursued. In respect of any such claim we can (and should) always ask who will benefit most from the proposed policies (Burchill 2005, 63-103), but this does not invalidate the concept. It remains useful so long as we recognize (i) that all claims about national interests involve the postulation of certain national goals, an interpretation of current and likely future conditions, and a process of reasoning about how those goals are best pursued under those conditions and (ii) that each of these individual elements, along with the whole, is intrinsically contestable. ${ }^{2}$

This approach to the national interest is both interpretive and loosely constructivist. It is constructivist insofar as understandings of the national interest are not only socially but also discursively constructed (see Weldes 1996). It is interpretive insofar as it analyzes the logic implicit within particular discursive constructions of the national interest. This does not imply that interests are a function either of identities or of international norms (see Burchill 2005, 193, 198-9): such arguments point back towards the identification of objective interests. My aim in analysing the discursive structure of claims about the national interest is not directly to explain particular foreign policies, but rather to unpack one way in which they may be justified. The implications for policy itself will be particular to each case. In some instances, a discursive analysis may reveal something of how policy is actually formulated: the discursive structure of claims about the national interest will reflect the pattern of thinking employed in formulating policy positions. In other cases, it may reveal an attempt, driven by political or bureaucratic 
interests, to impose conceptual coherence on policies that are largely already in place. In yet further cases, it may reveal the absence of any coherent justification, indicating that the national interest has been invoked to bolster sectional interests. My concern is not principally to identify such cases, but rather to develop the conceptual tools required to engage in such an analysis.

\section{Discursive Approaches to the National Interest}

Most claims about the national interest may be reconstructed in terms of one of two principal discursive structures. The first begins by postulating certain national goals and then engages in a process of reasoning about how those goals are best pursued under certain conditions. That reasoning may be understood as identifying national interests, though such interests may also be framed as proximate goals, making it possible in turn to identify more specific interests, and hence to explicate claims about the national interest at different levels of generality. The second starts by observing that the national community already enjoys certain goods to a certain extent and seeks to identify which existing foreign policy commitments deserve credit for that. Those commitments are identified as national interests, subject to estimates about the impact of future changes in conditions. I label these two discursive structures reformist and conservative (with a small-c): reformist approaches ask what national goals are appropriate and how they are best pursued; conservative approaches justify existing commitments in terms of the national goods they provide (Fig. 1).

Fig.1 Reformist approaches

\section{Desirable national goals \\ (ultimate or proximate) \\ $\downarrow$ (direction of reasoning) \\ Existing/likely future conditions $\downarrow$ \\ National interests}

Conservative approaches

\author{
National goods currently enjoyed \\ $\downarrow$ (direction of reasoning) \\ Existing commitments responsible
}

(Possible changes in conditions)

National interests

These two discursive structures are ideal-types. The purpose of distinguishing them is to help tease out the implications of claims about the national interest, thereby providing a means of holding policy-makers to account when they claim that a policy is in the national interest. I identify just two patterns of reasoning because if claims about the national interest link policies to underlying goals, then we can, crudely, either start with goals (a reformist approach) or with policies (a conservative approach). When it comes to analysing substantive claims, the ideal- 
types provide reference points: we unpack claims about the national interest by asking whether the required means-ends reasoning is present, explicitly or implicitly, and, if it is, where it starts and how it proceeds. This, in turn, facilitates debate about whether the proposed national goals are in fact desirable and whether the proposed policies are really the best available means of pursuing those goals. However, it is not a precondition of such analysis that individual claims about the national interest closely adhere to either ideal-typical structure. Indeed, ideal-types are likely to be most useful when there is not a perfect match (see Weber 2004, 388), such that the comparison reveals particular tensions or absences within the claims being analysed.

Conservative approaches identify existing commitments as responsible for current enjoyment of certain national goods and hence tend to promote continuity. For example, claims about the importance of maintaining Britain's standing in the world typically proceed by (i) associating current enjoyment of goods such as prosperity and security with Britain's ability to punch above her weight internationally, (ii) identifying particular aspects of existing policy, such as Britain's cross-cutting institutional memberships (see FCO 2003, 28), as maintaining that ability, and (iii) inferring that those policies (say, defending Britain's role as a permanent member of the UN Security Council) are in the national interest. A similar pattern may be observed in arguments for renewing Trident: the nuclear deterrent is identified as partly responsible for current levels of British security and renewing it is therefore inferred to be in the national interest. From the perspective of a conservative approach, therefore, the surprise expressed in the 2010 National Security Strategy [NSS] (HM Government 2010, 4) about the (claimed) constancy of Britain's interests is misplaced: it isn't surprising at all.

While conservative approaches are properly understood as justifying maintaining current commitments by reference to how they advance certain underlying national goals, those goals are not always specified. This may be because they are considered so obvious that elaboration is not required, yet Wolfers $(1962,72)$ argues that even such apparently basic goods as national survival, territorial integrity, and national independence may be conceived of in more or less extensive terms. A fully elaborated conservative approach therefore requires both specification of the goals that will be advanced by maintaining current commitments and an argument about how and why this will occur. More problematically still, some conservative approaches not only fail to specify ultimate goals, but also appear to treat interests as immune from challenge. For example, Wall (2011, xii, xiv) suggests that most British politicians possess an inherited sense of the national interest, implying that it requires little elaboration, let alone justification. Even if such unelaborated claims about the national interest have substance, which is doubtful, their 
elliptical form will tend to close down debate (see Gaskarth 2006), particularly in respect of the trade-offs implicit in all policy decisions (see Wolfers 1962,162).

Reformist approaches to the national interest are distinguished by the fact that they start with the explicit identification of the goals foreign policy seeks to advance and then reason from goals to interests. This creates space for the articulation of multiple policy objectives, providing a principled basis for expanding the national interest beyond a narrow association with national security. It also makes reformist approaches a critical tool for promoting change either in the goals of a nation's foreign policy or in the means of advancing them. In particular, claims about 'enlightened' national interests, which identify pursuit of proximate goods (such as order and peace) as means to the fulfilment of more fundamental goals (such as security and prosperity) are likely to follow a reformist pattern. This is apparent, for example, in Brown's (2009d, 83) appeal, at the Copenhagen climate change summit, that states should not suspend their national interests, but rather advance them 'more intelligently': he reasoned from fundamental goals (survival) through current conditions (climate change) to an account of national interests (as favouring a binding treaty). ${ }^{3}$ However, while thinking about foreign policy from first principles is conducive to change, the change is reformist rather than revolutionary (see Vickers 2011, 3): these approaches remain committed to a world of nation states. ${ }^{4}$

Both reformist and conservative discursive structures link interests to goals in a means-ends relationship. They therefore both raise questions about capabilities. Discussions of strategy often focus on goals, ways, and means, where goals are the objectives to be pursued, ways are the strategies by which they are pursued, and means are the capabilities required to prosecute those strategies. However, we must be cautious about incorporating capabilities into analyses of the national interest. The 1998 Strategic Defence Review [SDR] was intended to be foreignpolicy led (see Ministry of Defence 1998, 8) precisely in the sense that it would work out what principles should be advanced and then ask what composition of security capabilities would be required, rather than allowing a discussion of interests, and even of more fundamental goals, to be constrained by existing capabilities. Hence while claims about the national interest always carry implications for capabilities, they should not have to be justified by reference to existing capabilities. To insist that they are is to impose a conservative structure on such claims. ${ }^{5}$

The distinction between reformist and conservative approaches resonates to some (but only some) extent with party political divisions on foreign policy. Labour's internationalist tradition (see Vickers 2003, 193-207) explicitly appeals to first principles, while Conservative attempts to develop a national appeal have, since Disraeli's time, invoked the continuity of British interests 
and values. More recently, Robin Cook (1997) built his mission statement for the Foreign Office [FCO] around the specification of four core national goals (security, prosperity, quality of life in Britain, and, most controversially, 'the promotion of our values and confidence in our identity'), buttressed by a partial account of how those goals were to be advanced, viz. by securing 'the respect of other nations for Britain's contribution to keeping the peace of the world and promoting democracy around the world'. In contrast, William Hague (2010a, 2011) rejected 'the strategic shrinkage of Britain's influence in the world', criticized Labour's 'lack of sustained, systematic interest in the UK's bilateral relationships', and insisted that Conservative policies had 'stood the test of time'. His ambition for the FCO to 'provide the connection and ideas that allow the whole of the British state and British society to exercise maximum influence in the world' (Hague 2010b) in fact appears to imply that its task is simply to defend and promote whatever commitments the British state, its citizens, and especially its businessmen take on.

However, party political differences are easily overstated, not least because British parties are themselves broad churches. New Labour's foreign policy discourse was far from devoid of conservative reasoning, as revealed by Blair's (1997) assurances that he would sustain Britain's influence in the world. Conversely, David Cameron (2006) defended taking time, in opposition, to think through foreign policy from first principles and described 'liberal conservatism' as a 'new approach to foreign affairs'. His reasoning was reformist, even if he also cautioned against 'grand schemes to remake the world'. This qualification reflects the fact that whether reasoning is reformist or conservative depends on it structure rather than on its content or politics. For example, the coalition government has maintained Labour's commitment to reforming the UN security council, but if its reasoning is that this commitment has enhanced and will continue to enhance Britain's standing with rising powers such as Brazil (see Hague 2012), then this is a conservative approach, even if the policy itself is reformist. Similarly, if, rather than thinking from first principles about the national goals appropriate to contemporary British society and about how they are best advanced, the Labour party were merely to call for the maintenance of the liberal internationalist values already present within international society, then this would represent conservative reasoning, even though the content of the proposed policies would be broadly reformist. ${ }^{6}$ Equally, reformist reasoning can reinforce existing policies.

While the relationship between substance and form is intriguing, the purpose of differentiating ideal-typical patterns of reasoning is to facilitate critical scrutiny of the content and implications of foreign policy claims, rather than to generalize about who, what, and why. Both Cook and Hague make implicit claims about goals, interests, and the relationship between them and all such claims are appropriately subject to interrogation, facilitated by a focus on the discursive 
structures they employ. Cook's approach may be distinctive because it proceeds from first principles, but we should still evaluate the credibility of the national goals he articulates and the adequacy of his reasoning about how they are best advanced, just as we should scrutinize what (and whose) goals are really at stake in Hague's (2010b) desire to extend Britain's 'global reach and influence'. Such analysis does not require that actors explicitly employ a particular pattern of reasoning, that their substantive positions remain constant across time, or that their rhetoric is taken at face value. ${ }^{7}$ That said, the emergence of an increasingly explicit reformist approach to the national interest was, various inconsistencies notwithstanding, a notable feature of New Labour's foreign policy discourse. It is most strikingly evident in calls for global reform which, especially in Brown's hands, served to extend the content of the national interest well beyond its traditional ties to national security.

\section{New Labour's Reformist Discourse}

New Labour's use of reformist reasoning is notable partly because there are good reasons for expecting conservative approaches to prevail. While earlier foreign policy reviews did identify foreign policy goals, these were typically inferred from Britain's existing commitments, rather than providing a starting point for thinking about what those commitments should be. Even the Berrill Report (Central Policy Review Staff 1977), which of all the post-war reviews most clearly recognizes British decline, explicitly disavows any transformative goals, instead arguing that the EC offers the most likely route to maintaining British influence. ${ }^{8}$ Moreover, Sylvan \& Majeski $(2009,2)$ argue that in practice policy-making is often 'instrument-driven': bureaucracies react to new developments by adapting existing competencies and capabilities to new contexts. In other words, policy-making 'is not a matter of trying to achieve long-term structural goals', but rather of resolving short-term problems by applying available (already existing) means. This speaks strongly in favour of continuity and a conservative approach to the national interest, making it all the more striking that New Labour often explicitly began its reviews by asking what long-term goals foreign policy should serve.

Foreign Secretary Jack Straw introduced the 2006 FCO White Paper (FCO 2006, 4) by insisting that foreign policy must reflect 'a set of fundamental values' which also 'guide our action at home'. In other words, foreign and domestic policy should be continuous in advancing a core set of national goals. Straw argued, moreover, that the goals he articulated (including freedom, justice, accountability, and the protection of rights, security, and basic needs) were appropriate both because they were 'right' and because a world in which such goals are fulfilled 'is the best guarantee of the security and prosperity of people of the United Kingdom'. This suggests a 
hierarchy of goals in which the fundamental purpose of foreign policy is to provide security and prosperity but this in turn requires pursuit of various proximate goals. As the White Paper (FCO 2006,35 ) asserts: 'We need to support the aspirations of people around the world, including the most vulnerable, if our security and prosperity are to be lasting'. Britain's 'long term interests and values are best protected by the spread of democratic values, good government, and respect for human rights', because such developments 'make conflict less likely, reduce poverty and support sustainable development'.

These hierarchies of fundamental and proximate goals appear frequently in New Labour foreign policy pronouncements. For example, the 2003 FCO White Paper (which, Straw emphasized, was the first of its kind) insists that the objective of the FCO 'is not to promote "good relations" with other countries for the sake of it' but 'to make a positive difference in the world - for the benefit of people in the UK and elsewhere. Our purpose is to work for UK interests in a safe, just and prosperous world' (FCO 2003, 2,6). The 2008 NSS aimed to articulate a unified strategy for addressing a wide range of contemporary challenges, all with the ultimate goal of safeguarding 'the nation, its citizens, our prosperity and our way of life' (Cabinet Office 2008, 3). This kind of hierarchy is also sustained in the 2010 NSS, which begins by stating that security 'is the first duty of government. It is the foundation of our freedom and our prosperity' (HM Government $2010,9)$.

New Labour's foreign policy discourse also displays self-similarity across levels of abstraction. In other words, the hierarchies of fundamental and more proximate goals with which the White Papers start are also reproduced at more detailed levels. For example, having outlined the core goals of UK foreign policy, the 2006 White Paper identifies certain global changes (increasing complexity, uncertainty, and interdependence, and the increased role of non-state actors) as undermining unilateral efforts to advance states' objectives. This entails that in order to achieve its fundamental foreign policy goals the UK will need to work through a 'network of partners, allies and international institutions'. And this, in turn, entails that strengthening the capacity of such institutions, including through reform of the UN Security Council, is 'a key task' (FCO 2006, 22). The 2008 NSS (Cabinet Office 2008, 7) makes a slightly different argument, but employs a similar pattern of reasoning: it contends, first, that in a globalised world 'a multilateral approach ... brings not only greater effectiveness but also, crucially, greater legitimacy', second, that 'international institutions, from the UN Security Council to the World Bank, need to become more ambitious, effective and representative', and third, that the UK should therefore use its position 'to work for further reform'. As with the more abstract hierarchies, both these more 
specific arguments display a reformist logic: given Britain's underlying goals, and given current conditions, particular concrete policies are in the national interest.

An important feature of New Labour's reformist reasoning about the national interest is that it is often entangled with an emphasis on values. Indeed, the claimed coincidence of right conduct and interested action is a recurrent theme within New Labour's foreign policy discourse (see Blair 1999; Brown 2008b, 39). The reformist structure of its approach to the national interest provides important context for these claims. For example, although the SDR aspired for the UK to be a 'force for good in the world' (Ministry of Defence 1998,12), this was underpinned by the belief that socially conscientious action represents an important means of achieving national goals. Similarly, the 2008 NSS advocated defending 'core values' such as 'human rights, the rule of law, legitimate and accountable government, justice, freedom, tolerance, and opportunity for all' on the grounds that they 'form the basis of our security, as well as our well-being and our prosperity' (Cabinet Office 2008, 6). Although Cook (1997) sought to introduce 'ethical content to foreign policy' and to 'make Britain a leading partner in the world community of nations', the context of these aims was his belief that 'the national interest cannot be defined only by narrow realpolitik'. In short: value goals were pursued in part because they were viewed as a means to an end, that end being the more fundamental goals of British foreign (and also domestic) policy.

Of course, the fundamental goals identified in New Labour's foreign policy discourse are not only vague, but also rather prosaic: who would disagree that security, prosperity and freedom are a good thing? There was some attempt to spell out in more detail what those goals entailed: the 2008 NSS, for example, asks what security means in a globalized world and attempts to list contemporary security challenges (Cabinet Office 2008, 3-4, 10-24). We should, nonetheless, ask whether specific policies can really be inferred from such vague and all-encompassing goals. If they cannot, then use of reformist reasoning looks more like an attempt to provide a coherent justification for a set of policies that have already been decided upon than a genuine attempt to rethink foreign policy from first principles. Further evidence for such an interpretation might be provided by the influence of New Labour's target culture: the articulation of international priorities in the 2003 White Paper, for example, was explicitly driven by the need to identify targets for the FCO to fulfil in its 2003-06 Public Service Agreement with the Treasury (see FCO $2003,6) .{ }^{9}$ However, to object to New Labour's foreign policy discourse on the grounds that the appearance of a reasoned argument linking specific policies to more fundamental foreign policy goals is misleading is to object to the content of the discourse itself, rather than to the utility of a focus on discursive structure in unpacking that content. For it is only when we recognize that 
Labour's foreign policy discourse appears to adopt a reformist pattern of reasoning that we can then go on and ask: is this how policy was in fact formulated, or merely how it was defended?

\section{Reforming Global Order in the National Interest}

All claims about the national interest embody a certain understanding of international order, in the sense that they concern how national goals are best pursued under certain conditions. For example, Hague's (2010b) observations about how the world is changing (in the form of shifts in economic power, the limits to increased multilateralism, the increased complexity created by globalisation, the changing nature of conflict, and the emergence of a networked world) reflect a particular vision of the context provided by the prevailing order. Yet New Labour's calls for global reform go well beyond this engagement with order as context: echoing some of Labour's early internationalist ideas (see Vickers 2003), Brown and other New Labour leaders advocated profound changes to the rules of the game, changes that would result in the production of a new kind of global order.10 In this respect Brown's vision is the most intriguing, not only because he outlined a much more inclusive globality than is to be found in Blair's doctrine of international community (see Brown 2008a, 18; Ralph 2011, 127; Atkins 2013, 188), but also because he explicitly defended this expansive conception of global reform as being in the British national interest. His vision of a new global society therefore illustrates how far a reformist approach can extend the national interest beyond a narrow concern with national security.

Brown's first articulation of his ideas about global society appears in the context of an attempt to identify the challenges of an increasingly interdependent world (Brown 2008a, 18). Although he discusses these challenges without explicit reference to the national interest, he insists that

Acting upon our interdependence does not mean ... abandoning national interests. Instead, the very fact of interdependence requires nations to work out new ways of working founded on the recognition that they can best pursue their national interests by invoking broader global alliances (Brown 2008a, 23-4).

His thinking may therefore be reconstructed in accordance with a reformist pattern: he starts with the national goals typically associated with New Labour foreign policy, namely, security, prosperity, and justice; argues that new global challenges require those goals to be pursued in new ways; and infers that the British national interest includes global reform. This means-ends logic is clearest in three areas. First, the challenges Brown identifies, which encompass climate change, terrorism, nuclear proliferation, poverty and prosperity (Brown 2009b, 43; see also Brown 2009c, 49; Brown 2010a), clearly constitute obstacles to British security and prosperity. Second, Brown (2009a) explicitly argues that development is a means to global growth and 
prosperity and that institutional reform is a means to development and prosperity. Third, he explicitly identifies global reform as a means of confronting those global challenges which constitute obstacles to the fulfilment of British national goals (Brown 2009c, 50; Brown 2010a).

Brown's vision of a reformed global order goes beyond shuffling the seats at the top table. As with earlier New Labour calls for institutional reform (see FCO 2003, 24), he is committed to emerging powers playing a role in existing institutions (see Brown 2008b, 34), but he rejects as insufficient any solution to global problems which can 'be defined in terms of "us" and "them"' (Brown 2008b, 39). He also defends the existence of shared global values, arguing that 'through each of our diverse heritages there runs a single, powerful moral sense' and that 'there is a human need to cooperate ... built on the desire for liberty and the call to justice - respect for the dignity of every individual and our sense of what is equitable and fair' (Brown 2008a, 23). In calling for the creation of an 'architecture' that will 'bring to life these shared values' (Brown 2008a, 23), he seems to envision an order that is no longer structured around the idea of a top table. Even sceptics will admit that this is a rhetorically powerful vision, but Brown is resolute in linking it to UK national interests. He explicitly identifies in the idea of a global society an alternative to balance of power politics, arguing that global cooperation can no longer be 'founded just on balancing competing interests', but instead requires 'institutions that foster mutual interests because they are grounded in common values' (Brown 2008a, 22). Yet he insists that this does not mean abandoning national interests. Rather, national interests can 'be protected only by serving the common interest' (Brown 2009b, 43): it is necessary to reject a narrow conception of the national interest (see Brown 2009d, 83).

Focusing on the discursive structure of Brown's claims therefore provides a helpful perspective on a controversial interpretive issue. To the extent that global reform is justified as serving the British national interest, New Labour cannot be said to have 'taken a principled stance on world affairs, rather than simply focusing on the protection of UK interests': New Labour did not argue that the UK should 'work in the "international" interest rather than ... [the] national interest'. New Labour cannot even strictly be said to have pursued 'the international interest as well as the national interest' (Kitchen and Vickers 2013, 300-1). The problem with such formulations is that they invoke a narrow conception of the national interest, associating it with the protection of national security, narrowly construed (see Vickers 2011, 10-14): it is only if we accept this as a definition of the national interest that the contrast with the international interest makes sense. But for Brown, a reformed global order is not just a good, but a national interest: it is a means by which Britain can fulfil her national goals in a globalised world. What the reformist structure of New Labour's foreign policy discourse reveals above all else is that the national interest does 
not have to be defined in traditional terms. Importantly, this is true whether that discourse reflects how policy is formulated or merely how it is justified: even if New Labour merely sought to justify policy positions adopted for other reasons, the way in which it went about this implies that a narrow conception of the national interest is equally in need of justification.

\section{Conclusion}

The recalcitrance of the concept of the national interest is, for many, frustrating: regarding it as a largely vacuous means of ideological suasion, they believe it should be discarded forthwith. Yet the concept is not necessarily empty: claims about the goals nations should pursue and about how they are best advanced are potentially both meaningful and important. Problems arise only when the national interest is presented or thought of as being objective. In reality, it is inherently politicized, and hence intrinsically contestable. One way of approaching claims about the national interest is therefore critically to analyse the means-ends reasoning which is a necessary part of meaningful claims about the national interest, but which is nonetheless often implicit or incomplete. The ideal-typical reformist and conservative structures of reasoning outlined above are designed to facilitate such analysis.

This approach does not constitute a panacea. First, in filling out the logic behind claims about the national interest, identifying patterns of reasoning may be necessary but insufficient. Where goals are vague or various means of advancing them are available, appeals to national identity or role conceptions (see Gaskarth 2011; McCourt 2011) may be required to fill the gaps. A focus on discursive structure therefore complements, but does not supersede, other approaches. Second, there is not a determinate relationship between discursive structure and policy content. Either reformist or conservative reasoning could, given the right context, be employed to justify almost any policy. The point of distinguishing them is not, therefore, to show that one is better than the other (though critics of existing policies are, for obvious reasons, likely to prefer a reformist approach) but rather to show that means-ends reasoning is required for a claim about the national interest to be meaningful and that there are just two main patterns that it can follow. Third, to identify the pattern of reasoning is not yet to identify whether that reasoning is being employed as a means of making policy or as a means of justifying policy that has already been determined upon based on other considerations. It is, though, a prerequisite of asking that question in an incisive fashion.

Applying this approach to New Labour's foreign policy discourse reveals the extent to which it utilised reformist reasoning, approaching the national interest by first specifying the goals that 
foreign policy is intended to advance. This is notable not least because of the many reasons why a conservative approach might prevail, as it has throughout much of Britain's post-war foreign policy discourse. More fundamentally, such reformist reasoning is a condition of the expansion in the content of the national interest implied by the claim that global reform is in the British national interest. This is not to say that the reformist structure of this reasoning reflects how (let alone why) particular policies were formulated. Indeed, it is striking that New Labour justified some of the most transformative aspects of its foreign policy as advancing such prosaic (and vague) national goals as security and prosperity. But even if reformist reasoning merely justified New Labour's approach to global reform, the implication remains: the national interest cannot simply be equated with national security. Hence although Brown's vision does raise problematic questions about the extent of the common values to be found at the global level, it is wrong to say that he conflated UK goals and interests with those of a putative (even fanciful) global society (Gaskarth 2011, 95-6). This is, once again, to fall back on a traditional conception of the national interest, whereas the key implication of New Labour's position is that in a globalized world Britain's core national goals can only be achieved through a much expanded conception of the national interest.

Showing how Gordon Brown used a reformist approach to identify global reform as a national interest invites us to ask whether the goals his policies sought to advance are really national goals and whether he presents an adequate argument as to how global institutional reform will help Britain to achieve those goals. Conversely, if the Conservative party tends to fall back on a conservative approach focused on maintaining British influence, then this invites us to ask what goals that influence is designed to serve: in short, who benefits? More broadly, a discursive approach exposes where the reasoning that gives content to claims about the national interest is absent or incomplete, reveals where claims may have political traction even though they are incomplete, and facilitates interrogation of (i) when goals and interests may conflict, (ii) when alternative means of advancing goals are available, and (iii) who benefits from the proposed policies. These critical tasks draw on a theoretical approach which starts by asking, in idealtypical terms, what an adequate claim about the national interest must look like. This kind of theory is not capable of generating the testable hypotheses so prized by mainstream IR, but it can underpin a distinctive academic contribution to important political and policy debates. 


\section{Notes}

${ }^{1}$ Whereas Blair (1999) claimed that 'we are all internationalists now, whether we like it or not', Brown $(2008 \mathrm{a}, 18)$ observed that 'to say we are all internationalists now, will change nothing in itself'. Dyson (2011) explores differences in their worldviews, but assertions of continuity are more common (see Daddow 2011, 222; McCormack 2011, 105; McCourt 2011, 45).

${ }^{2}$ An 'uncontested sense of the national interest' (Edmunds 2012, 281) is therefore not an unqualified good.

${ }^{3}$ Hague (2010a, 2010b) also talks of 'enlightened' national interests, though the reasoning giving content to that notion is less clear.

${ }^{4}$ This is true even of Mark Malloch-Brown (2011), probably the most committed internationalist among Labour ministers and an important influence on Brown's vision of a new global society.

${ }^{5}$ Edmunds $(2012,270)$ discusses the flaws in a capabilities-based approach to strategy. In practice, the SDR falls into conservative reasoning, asking how existing commitments match up to current circumstances and likely future threats.

${ }^{6}$ I am grateful to a reviewer for emphasizing this point.

${ }^{7}$ One way in which politicians' language diverts from my ideal-types is that they often reverse my hierarchy of goals and interests, talking about more proximate goals serving core or longterm interests. In my view, the hierarchical logic is more important than the terms employed. ${ }^{8}$ Wheeler and Dunne $(1998,847-8)$ therefore regard Cook (1997) as providing the first new conceptual framework for British foreign policy for fifty years ${ }^{9}$ A reviewer suggested that my reformist/conservative distinction might really be a political/bureaucratic distinction: political leaders provide the (reformist) vision and (conservative) bureaucrats work out the details. This may capture an important aspect of the policy process, but it does not work as a claim about structures of reasoning, as revealed by the apparent influence of a bureaucratic tool (Treasury targets) in motivating reformist reasoning about foreign policy.

10 This is not to deny that Hague, or indeed the Conservative party, may at times also have developed a more transformative approach to global order. 


\section{Bibliography}

Atkins, J. (2013) 'A renewed social democracy for an "age of internationalism": An interpretivist account of New Labour's foreign policy, British Journal of Politics and International Relations, 15:2, 175-91.

Blair, T. (1997) Speech to the Lord Mayor's Banquet, Guildhall, London, 10 November http://webarchive.nationalarchives.gov.uk/20070701080624/http://www.pm.gov.uk/ output/Page1070.asp (accessed 11 September 2013).

Blair, T. (1999) Speech to the Economic Club, Chicago, 24 April http://www.britishpoliticalspeech.org/speech-archive.htm?speech=279 (accessed 11 September 2013).

Brown, G. (2008a) Speech delivered at the Kennedy Presidential Library and Museum, Boston, 18 April, in Brown (2010b), 17-29.

Brown, G. (2008b) Speech to the Lord Mayor's Banquet, Guildhall, London, 10 November, in Brown (2010b), 32-40.

Brown, G. (2009a) Speech at Department for International Development, London, 9 March http://webarchive.nationalarchives.gov.uk/20100429125008/http://www.number10. gov.uk/news/speeches-and-transcripts/2009/03/speech-to-dfid-conference-oneliminating-world-poverty-18554 (accessed 11 September 2013).

Brown, G. (2009b) Speech to the UN General Assembly, New York, 23 September, in Brown (2010b), 43-7.

Brown, G. (2009c) Speech to the Lord Mayor's Banquet, Guildhall, London, 16 November, in Brown (2010b), 49-57.

Brown, G. (2009d) Speech to the UN Climate Change Conference, Copenhagen, 17 December, in Brown (2010b), 81-3.

Brown, G. (2010a) Remarks at the Foreign Press Association, London, 19 March http://webarchive.nationalarchives.gov.uk/20100429125008/http://www.number10. gov.uk/news/speeches-and-transcripts/2010/03/opening-remarks-at-fpa-event-22876 (accessed 11 September 2013).

Brown, G. (2010b) The Change We Choose: Speeches 2007-2009 (Edinburgh: Mainstream).

Bull, H. (2002 [1977]) The Anarchical Society: A Study of Order in World Politics, $3^{\text {rd }}$ ed. (Basingstoke: Palgrave).

Burchill, S. (2005) The National Interest in International Relations Theory (Basingstoke: Palgrave Macmillan).

Cabinet Office (2008) The National Security Strategy of the United Kingdom: Security in an Interdependent World. Cmd. 7291. 
Cameron, D. (2006) Speech to the British American Project, 11 September http://www.theguardian.com/politics/2006/sep/11/conservatives.speeches (accessed 19 December 2013).

Central Policy Review Staff (1977) Review of Overseas Representation: Report (London: HMSO).

Cook, R. (1997) Speech delivered at the FCO, London, 12 May http://www.britishpoliticalspeech.org/speech-archive.htm?speech=292 (accessed 11 September 2013).

Daddow, O. (2011) 'Conclusion', in Daddow \& Gaskarth (2011), 221-35.

Daddow, O. and J. Gaskarth (eds.) (2011) British Foreign Policy: The New Labour Years (Basingstoke: Palgrave Macmillan).

Dyson, S. B. (2011) 'New Labour, leadership, and foreign policy-making after 1997', in Daddow \& Gaskarth (2011), 63-83.

Edmunds, T. (2012) 'British civil-military relations and the problem of risk', International Affairs, 88:2, 265-82.

Foreign and Commonwealth Office (2003) UK International Priorities: A Strategy for the FCO. Cmd. 6052.

Foreign and Commonwealth Office (2006) Active Diplomacy for a Changing World: The UK's International Priorities. Cmd. 6762

Gaskarth, J. (2006) 'Discourses and ethics: The social construction of British foreign policy', Foreign Policy Analysis, 2:4, 325-41.

Gaskarth, J. (2011) 'Identity and New Labour's strategic foreign policy thinking', in Daddow \& Gaskarth (2011), 84-99.

Hague, W. (2010a) Speech delivered at the Royal United Services Institute, London, 10 March http://www.conservatives.com/News/Speeches/2010/03/William Hague The biggest risk for Britain is five more years of Brown.aspx (accessed 11 September 2013).

Hague, W. (2010b) Speech delivered at the FCO, London, 01 July http://www.conservatives.com/News/Speeches/2010/07/William Hague Britains For eign Policy in a Networked World.aspx (accessed 11 September 2013).

Hague, W. (2011) Speech delivered at the FCO, London, 08 September https://www.gov.uk/government/speeches/the-best-diplomatic-service-in-the-worldstrengthening-the-foreign-and-commonwealth-office-as-an-institution (accessed 11 September 2013).

Hague, W. (2012) Speech delivered in Rio de Janeiro, 19 January http://www.politics.co.uk/comment-analysis/2012/01/20/william-hague-s-latinaerica-speech-in-fullm [sic] (accessed 19 December 2013) 
HM Government (2010) A Strong Britain in an Age of Uncertainty: The National Security Strategy. Cmd. 7953.

Kitchen, C. and R. Vickers (2013) 'Labour traditions of international order and the dilemma of action towards Iran', British Journal of Politics and International Relations, 15:2, 299-316.

Kratochwil, F. (1982) 'On the notion of "interest" in international relations', International Organization, 36:1, 1-30.

Malloch-Brown, M. (2011) The Unfinished Global Revolution: The Limits of Nations and the Pursuit of a New Politics (London: Allen Lane).

McCormack, T. (2011) 'From "ethical foreign policy" to national security strategy: Exporting domestic incoherence', in Daddow \& Gaskarth (2011), 103-22.

McCourt, D. (2011) 'The New Labour governments and Britain's role in the world', in Daddow \& Gaskarth (2011), 31-47.

Ministry of Defence (1998) Strategic Defence Review. Cmd. 3999.

Morgenthau, H. J. (1973 [1948]) Politics Among Nations: The Struggle for Power and Peace, $5^{\text {th }}$ ed. (New York: Alfred A. Knopf).

Nye, J. (1999) 'Redefining the national interest', Foreign Affairs, 78:4, 22-35.

Ralph, J. (2011) 'A difficult relationship: Britain's "doctrine of international community" and America's "war on terror"', in Daddow \& Gaskarth (2011), 123-38.

Seldon, A. and G. Lodge (2010) Brown at 10 (London: Biteback).

Sylvan, D. and S. Majeski (2009) U.S. Foreign Policy in Perspective: Clients, Enemies and Empire (London: Routledge).

Vickers, R. (2003) The Labour Party and the World, Vol.1: The Evolution of Labour's Foreign Policy 1900-51 (Manchester: Manchester University Press).

Vickers R. (2011) The Labour Party and the World, Vol.2: Labour's Foreign Policy Since 1951 (Manchester: Manchester University Press).

Wall, S. (2011) 'Foreword', in Daddow \& Gaskarth (2011), xii-xv.

Weber, M. (2004 [1904]) 'The "objectivity" of knowledge in social science and social policy', in S. Whimster (ed.), The Essential Weber: A Reader (London: Routledge), 359-404.

Weldes, J. (1996) 'Constructing national interests', European Journal of International Relations, $2: 3,275-318$.

Wheeler, N. J. and T. Dunne (1998) 'Good international citizenship: A third way for British foreign policy', International Affairs, 74:4, 847-70.

Williams, M. C. (2004) 'Why ideas matter in international relations: Hans Morgenthau, classical realism, and the moral construction of power politics', International Organization, 58:4, 633-665. 
Wolfers, A. (1962) Discord and Collaboration: Essays on International Politics (Baltimore: Johns Hopkins Press). 